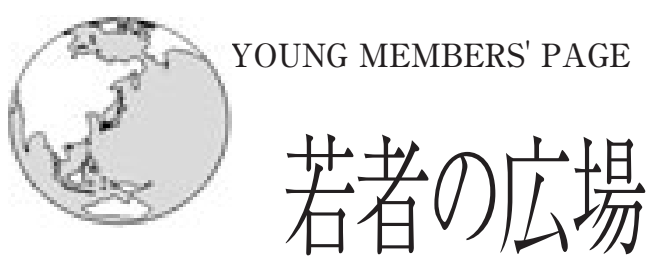

$「$ 平成 17 年度前期ならびに後期（第 20 回，21回）若手研究者の国際交流支援」による助成を受けて，海外学会に参加した 若手会員からの報告を紹介する。なおスペースの関係上, 会議概要ならびに指導教官および助成に対する謝意の部分を原文か ら割愛したことを打断りしておく。

\title{
56th Annual Meeting of the International Society of Electrochemistry (ISE)
}

2005年 9 月 25 日から 30 日まで韓国・釜山の臨海地帯にあるコンベンション施設Busan Exhibition \& Convention Center (BEXCO) で開催され、1100件以上の研究が発表された.

会議は, 追って行われる「アジア太平洋経済協力会議（APEC）」のために, 警官・軍人が時折, 会場周辺を監視する状況 の下で行われた.

浅野 直紀 (山梨大学大学院博士後期課程)

国際学会への参加は今回が 2 度目でしたが，台風と縁があ るのか 2004 年電気化学会日米合同大会と同様に，今回も飛 行機が遅延となり初日から足止めされてしまいました。しか し，前回のように久航にはならなかったので飛行機に搭乗し た際は大変安堵しました。今回，主催者のお陰により，良い ホテルを格安で提供していただき，私の宿泊したホテルは， ビーチ沿いの夜景がきれいで，感激するほどの広さと清潔感 のあるホテルでありました。金銭的に余裕のあまりない私た ち学生にとって良い思い出となったと感じたのは私だけでな いでしょう。

学会期間中は主にFuel Cell と Young セッションで数多く の発表を扯聴させていただきましたが，どの発表に関しても 活発に討論されていました。そのので私は，4 日目の昼から のヤングポスターセッションに「Proton Conductive Polyimide Ionomers With Branching Structure」という題 目で発表いたしました。内容は固体高分子形燃料電池の電解 質膜として，新型の炭化水素系電解質である（スルホン酸化 ポリイミド）を提案し，特に，分枝・架橋による電解質特性 の効果について報告しました。一般的に，炭化水素系電解質 膜は明確な親水/疎水性相分離構造を形成しにくいため, 低 湿度でのプロトン伝導率の大幅な低下が起こります。この低 下を抑制するために，イオン交換当量を増加させ，極微量の 架橋剂を添加したスルホン酸化ポリイミドを合成しました。 架橋の効果により耐水性, 機械的強度, さらにはプロトン伝 導率の向上に成功しました。昼食を挟んだ時間帯ではありま したが多くの方にポスターを見に来ていただきうれしく思い ました。また，ヤングセッションでの発表でありましたので 専門分野ではない研究者の方々とも意見を交わし，異なる角 度からの意見を頂くことができ，非常に良い刺激となりまし た．その中でも本研究の特徵と利点を十分にアピールするこ とが出来たのではないかと自負しています。多くの質問は実 際に燃料電池として作動させたことがあるかでありました。 やはり, 電解質膜のみの特性評価だけでなく実作動させた時 の特性, 安定性について関心が集中していることを切に感じ, 今後, 更なる評価を行う必要を強く感じました。この国際学 会を通して国際的な研究動向を知ることが出来たこと，同じ
分野における研究者とコミュニケーションが取れたこと，ま た，プレゼンテーションの多様性について学ぶことができ， 非常に有意義な経験を得ることができました。この経験を今 後に活かすことができればと考えています。

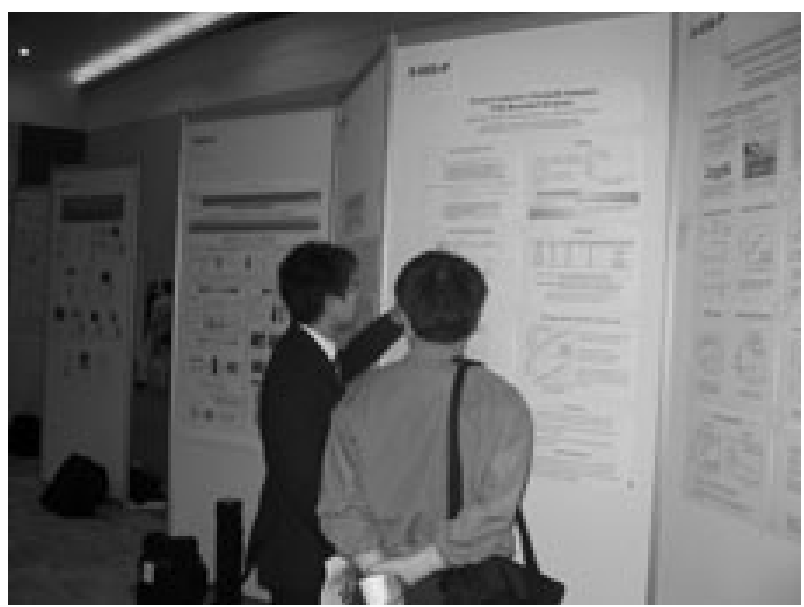

飯田 広範（早稲田大学院理工学研究科）

開催都市は韓国・釜山で, 距離としては日本からとても近 く, 私が滞在したホテルには福岡から来た修学旅行生も宿泊 しているというものでした．環境的にも日本と大差はなく， 解読の難しい文字と必要以上に辛い食事以外は惑いを感じる ことはありませんでした。

私の発表は会期の 5 日目で, 当日までに会場の雾囲気も把 握していましたし，釜山の環境にも慣れてきた頃でしたので リラックスして臨むことができました. 今回はポスター形式 での発表でしたので，これが一番の要因だったのかも知れま せん．私自身としては，今回の発表を一区切り的に位置付け ていましたので, 研究のアイディアについてアピールするこ とに専念しました．幾人の方が私を訪れ，これに対して的確 な指摘や，思いもよらなかった視点からの意外なコメントを 下さいました．また，今回のために新調した名刺も数枚交換 する機会があり，同世代の国際的研究同志を得ることができ たことも非常に貴重な経験でした．同時に，英語も含め，ま だまだ自分には知識も経験も全く足りていないことを改めて 
痛感させてくれました。(写真は隣のポスターの発表者と濃 密な議論をしているところで, 自分の研究についても考えさ せられるところがありました.）

一方，その他の発表はというと，私は分析，バイオ，物理 化学を主題とした会場を中心に聴いて回っていましたが，い ずれの会場も活気に満ち溢れており，座長の方がザックリ切 り上げてしまう場面も間々見られました。さらには，著名な 先生の招待講演を始めとした多くの講演を聴くことで新しい アイデイアを得ることができ，貴重な御土産として持って州 ってくることができました.

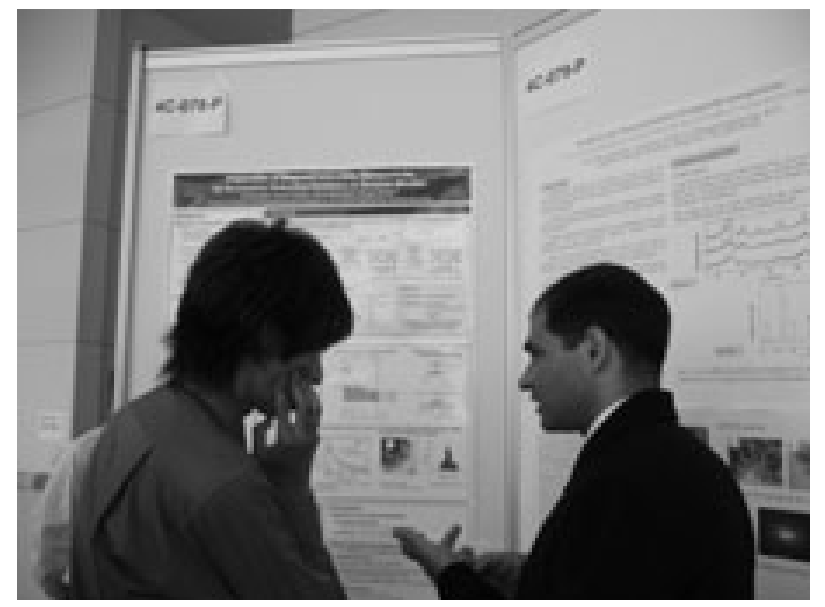

奈良 洋希 (早稲田大学院理工学研究科)

わたしは “Application of diblock polymer gel electrolyte having micro phase separation structure to lithium secondary batteries”というタイトルでポスターセッション に参加した．内容はイオン導電性を示すポリマー鎖と機械的 強度を示すポリマー鎖が化学的に結合しているジブロックポ リマーを用いてリチウム二次電池用ゲル電解質を作製し，そ の特性を評価した結果，一般的な有機系電解液に比べリチウ ム金属負極と非常に安定した界面を形成するといったもので あった．参加したセッションの “3A-batteries” の会場は広 くエネルギーに関する研究が多く行われていることを改めて 実感させられた。しかし，ポスター発表の時間は午前中の発 表が終わった直後からということもあり，会場にいる人はま ばらであり，自分のポスターの前でディスカッションしてい る人などを見るとうらやましかったものである。しかし，時 間が経つにつれてわたしのポスターにも興味を示す人が現れ，
片言であるが英語でのディスカッションを行い，また他分野 の発表も扯聴し，今後の研究のヒントとなりえる知見を得る ことができ，大変刺激的かつ有益なものであった．

また，韓国に行って痛感したのは英語のありがたみである. わたしは英語が得意ではないが一度も習ったこともない韓国 語と比べればとても使いやすいコミュニケーションッールで ありホテルにあったコンビニでは安心して買い物ができた。 とはいうものの夜はガイドブック片手に街に出て韓国料理を 堪能し現地の雲囲気を満喫した。これら国際学会での経験, 海外での経験を今後に活かしていけたらと思う。
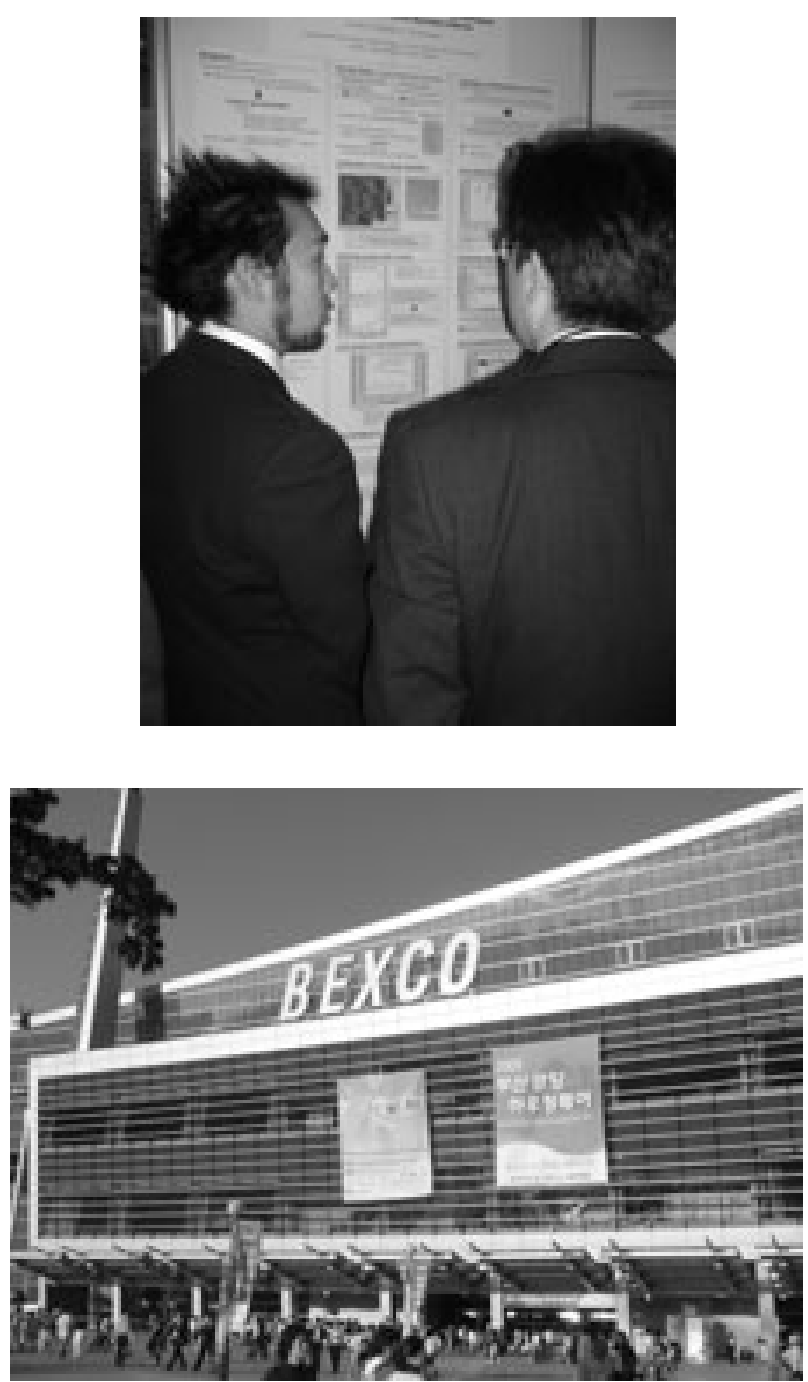

\section{8th Meeting of the Electrochemical Society (ECS)}

2005 年 10 月 16 日から 21 日まで, カルフォルニア州ロサンゼルス市のダウンダウン高層ビル群に位置する, The Westin Bonaventure Hotelにて開催され, 約1300 件の口頭及びポスター発表が行われた. 会場は全面ガラス張りの $5 つ$ 円筒型タ ワーから構成されたランドマーク的存在で, その風貌から学会期間中も含めて何度も映画の撮影に使われている.

藪内 直明（大阪市立大学大学院工学研究科） 私はリチウムイオン蓄電池に関する研究を扱う「D2」セ ッションに招いて, 学会二日目に「Lithium Insertion Material of $\mathrm{LiCo}_{1 / 3} \mathrm{Ni}_{1 / 3} \mathrm{Mn}_{1 / 3} \mathrm{O}_{2}$ for Advanced Lithium-Ion Batteries」というタイトルで口頭発表を行わせていただきま した. 内容はリチウムイオン蓄電池用の新規正極材料として
注目されている「層状コバルトーニッケルーマンガン三元系 リチウムインサーション材料」に関して, 材料の合成手法, マクローミクロ的視点からみた結晶構造とその電子状態, 第 一原理計算を用いた充放電反応機構の解明, そして直流一交 流法を用いた充放電特性評価など, 修士, 博士と 5 年間にわ たり大学院で行ってきた研究を総括するような内容で報告さ 